\title{
STUDI LITERATUR: PENGARUH KAWASAN PENDIDIKAN PERGURUAN TINGGI TERHADAP PERUBAHAN GUNA LAHAN
}

\author{
Shofia Luthfiatin, Mohammad Agung Ridlo \\ Program Studi Perencanaan Wilayah dan Kota Universitas Islam Sultan Agung Semarang \\ Email korespondensi: shovialuthfi96@gmail.com
}

\begin{abstract}
College activity became one of the influences to change land use. Presence college activity can cause other activities like increasing demand for land, an increase in economic cause community request and others. This study uses literature study in influences to change of land use, with taking case study in UNNES, HALUOLEO, UNSOED, IPB, UNDIP, and other universities in Yogyakarta. The result of this study can be concluded that college activities have a role in the change of land use. College activity can be forms the land use and other activity that grow from the presence of college activity like an increase in economy and another infrastructure.
\end{abstract}

Keyword: land use, college activity, university

\section{ABSTRAK}

Aktivitas perguruan tinggi menjadi salah satu yang mempengaruhi perubahan penggunaan lahan. Adanya perguruan tinggi dapat menimbulkan aktivitas-aktivitas lainnya seperti meningkatnya permintaan kebutuhan lahan, perekonomian yang meningkat karena sebuah permintaan dari kehidupan masyarakat baik pendatang maupun masyarakat asli. Penelitian ini menggunakan studi literatur pengaruh perubahan penggunaan lahan, dengan mengambil studi kasus di UNNES, HALUOLEO, UNSOED, IPB, UNDIP, dan Perguruan Tinggi Yogyakarta. Hasil dari kajian tersebut dapat disimpulkan bahwa adanya aktivitas perguruan tinggi mempunyai peran dalam perubahan penggunaan lahan. Aktivitas perguruan tinggi dapat membentuk tatanan lingkungan dalam hal pola penggunaan lahan dan juga aktivitas lain yang tumbuh dari adanya aktivitas perguruan tinggi seperti perkonomian dan juga sarana prasarana.

Kata Kunci: penggunaan lahan, aktivitas kampus, universitas 


\section{PENDAHULUAN}

Eksistensi suatu perguruan tinggi di suatu kawasan atau suatu daerah akan menyebabkan dampak diantaranya mengakibatkan banyak alih fungsi lahan terutama huma non-terbangun menjadi huma terbangun, memicu banyaknya timbul pertokoan, semakin bertambah padatnya suatu daerah oleh bangunan-bangunan, meningkatnya kualitas infrastrukutur yang ada, serta banyaknya mix-use fungsi bangunan-bangunan perumahan.

Penggunaan lahan pada suatu daerah bisa terdiri dari permukiman, industri, komersil, jalan, tanah publik, serta tanah kosong. Terjadinya perubahan penggunaan lahan mampu dikaitkan oleh banyak sekali kegiatan baru yang bisa mempengaruhinya. Dimana kebutuhan lahan akan semakin tinggi mengingat kebutuhan masyarakat sebagai penduduk permanen pada daerah tersebut. Kebutuhan itu tak hanya diperuntukkan sebagai permukiman namun pula kebutuhan lainnya yang sama seperti perdagangan jasa yang akan memenuhi kebutuhan masyarakat lainnya.

Ketersediaan lahan pada kawasan Pendidikan Perguruan Tinggi semakin menipis setiap tahunnya sebab banyaknya penduduk baru sebagai pendatang di daerah tersebut. Maka sebagian masyarakat memanfaatkan adanya penduduk baru dengan memperluas serta berbagi kebutuhan- kebutuhan seperti pembangunan lahan kosong sebagai terbangun dapat dijadikan sebagai lokasi tempat tinggal serta kegiatan perdagangan dan jasa yang membutuhkan lahan relatif banyak. Adanya kawasan baru juga bisa menumbuhkan perekonomian masyarakat asli daerah tersebut.

Sesuai dengan uraian yang ada, salah satu faktor yang dapat mempengaruhi perubahan lahan adalah adanya pertumbuhan baru pada suatu daerah atau kawasan, seperti adanya kawasan pendidikan perguruan tinggi yang dapat menjadi pemicu dalam berkembangnya kegiatan lain. Maka, pada studi pengaruh kawasan pendidikan perguruan tinggi terhadap perubahan penggunaan lahan akan dikaitkan pada studi kasus yang membahas adanya perubahan lahan terjadi karena aktivitas atau kegiatan baru.

\section{LITERATUR}

\section{a. Kawasan Pendidikan Perguruan Tinggi}

Pendidikan Perguruan Tinggi merupakan tumpuan akhir seluruh jenjang pendidikan dan sebagai wahana pembentukan sarjana yang memiliki budi pekerti luhur, 
melangsungkan nilai-nilai kebudayaan, memajukan kehidupan dan membentuk satria pinandita (Harsono, 2008: 22). Pada pasal

5 Undang-undang Republik Indonesia Nomor 12 Tahun 2012 Tentang Pendidikan

Perguruan Tinggi, menjelaskan bahwa Pendidikan Perguruan Tinggi bertujuan:

1. Berkembangnya potensi Mahasiswa agar menjadi manusia yang beriman dan bertakwa kepada Tuhan Yang Maha Esa dan berakhlak mulia, sehat, berilmu, cakap, kreatif, mandiri, terampil, kompeten, dan berbudaya untuk kepentingan bangsa;

2. Dihasilkannya lulusan yang menguasai cabang Ilmu Pengetahuan dan/atau Teknologi untuk memenuhi kepentingan nasional dan peningkatan daya saing bangsa;

3. Dihasilkannya Ilmu Pengetahuan dan Teknologi melalui Penelitian yang memperhatikan dan menerapkan nilai Humaniora agar bermanfaat bagi kemajuan bangsa, serta kemajuan peradaban dan kesejahteraan umat manusia; dan

4. Terwujudnya Pengabdian kepada Masyarakat berbasis penalaran dan karya Penelitian yang bermanfaat dalam memajukan kesejahteraan umum dan mencerdaskan kehidupan bangsa.

\section{b. Pengertian Penggunaan Lahan}

Istilah penggunaan lahan dikaitkan dengan aktivitas manusia yang dilakukan terhadap lahan tersebut. Istilah penggunaan lahan banyak dikemukakan oleh para ahli. Penggunaan lahan menurut Soegino (1987) diartikan sebagai suatu aktivitas manusia pada lahan yang langsung berhubungan dengan lokasi dan kondisi lahan. Sedangkan pengertian penggunaan lahan menurut Jayadinata (1999) mengatakan bahwa penggunaan lahan adalah wujud atau bentuk usaha kegiatan pemanfaatan suatu bidang tanah pada satu waktu.

\section{c. Perubahan Penggunaan Lahan}

Perubahan penggunaan lahan memiliki beberapa karakter yang dapat mempengaruhi seperti sebaran ruang, jenis guna lahan, dan luas lahan. Besaran pemanfaatan pemggunaan lahan ialah besaran lahan yang dimanfaatkan pada kegiatan atau suatu system kegiatan berada. Sedangkan faktor yang dapat berpengaruh pada pengembangannya adalah kelerengan, penduduk, harga lahan, aksesibilitas, sarana prasarana, dan DDL (daya dukung lingkungan). Berikut adalah system yang dapat mempengaruhi yaitu (Chappin,1979:28-31) Sistem Aktivitas Kota, Sistem Pengembangan Lahan, dan Sistem Lingkungan. 
Tabel 1 Sistem Pengaruh Guna Lahan

\begin{tabular}{|c|l|l|}
\hline No & \multicolumn{1}{|c|}{ Pemeran } & \multicolumn{1}{c|}{ Kegiatan } \\
\hline 1 & Individu \& Keluarga & $\begin{array}{l}\text { Kegiatan Keluarga } \\
\text { Kegiatan Bersosial/Bermasyarakat } \\
\text { Kegiatan Rekreasi } \\
\text { Kegiatan Berbelanja } \\
\text { Kegiatan Bekerja }\end{array}$ \\
\hline 2 & Perusahaan & $\begin{array}{l}\text { Kegiatan Memproduksi Barang } \\
\text { Kegiatan Memberikan Jasa }\end{array}$ \\
\hline 3 & Institusi & $\begin{array}{l}\text { Pengembangan SDM } \\
\text { Kegiatan Pelayanan Publik }\end{array}$ \\
\hline
\end{tabular}

\section{METODOLOGI}

Studi literatur yang digunakan dalam penelitian adalah kajian studi perguruan tinggi yang berada di UNNES, HALUOLEO, UNSOED, IPB, UNDIP, dan Perguruan Tinggi Yogyakarta. Alasan dari pemilihan studi kasus adalah adanya persamaan dari kasus yang akan diteliti. Seperti pada studi kasus UNNES membahas terkait faktor-faktor yang mempengaruhi pola penggunaan lahan oleh adanya keberadaan kampus UNNES, kemudian pada studi kasus HALUOLEO membahas terkait perubahan tata guna lahan dan pada UNSOED membahas perubahan morfologi kawasan sekitar perguruan tinggi.

\section{HASIL DAN PEMBAHASAN}

Pada sub bab ini akan menjelaskan terkait dengan perubahan penggunaan lahan dari beberapa penelitian sebelumnya. Adapun studi kasus yang akan dibahas dalam sub bab ini adalah UNNES, HALUOLEO, UNSOED, IPB, UNDIP, dan Perguruan Tinggi Yogyakarta (Afriani, 2014; Buchori, 2015; Prasetyo dan Hariono, 2014; Pratiwi dan Agustina, 2017; Wulangsari, 2013; Ningsih, 2017). Penelitian yang akan dibahas adalah perubahan penggunaan lahan dikarenakan adanya aktivitas perguruan tinggi pada masing-masing kawasan.

\section{A. Studi Kasus "Pengaruh Keberadaan Universitas Haluoleo Terhadap Perubahan Tata Guna Lahan Di Kawasan Andonuohu Kota Kendari”}

Universitas haluoleo membawa dampak pada perkembangan kawasan yaitu perubahan pola guna lahan terlebih pada daerah Andonuohu. Perubahan penggunaan lahan berupa lahan kosong sebagai lahan terbangun karena banyak lahan kosong yang terdapat pada kawasan sekitar. Tetapi adanya universitas memberi perubahan yaitu suatu 
perkembangan seperti tata guna lahan dan perekonomian. Kegiatan yang terjadi dari hasil observasi yang sudah dilakukan, bahwa keberadaan Universitas Haluoleo, memiliki pengaruh terhadap pola perubahan lahan, dampak bertambah munculnya kegiatan pemenuhan kebutuhan mahasiswa dan penduduk sekitar.

Universitas Haluoleo memberikan pengaruh pada perkembangan aktivitas baik ekonomi maupun sosial di kawasan sekitar kampus. Kegiatan muncul karena dipengaruhi universitas secara langsung (backward linkage) atau pendukung kegiatan sebelumnya (forward linkage). Kegiatan forward linkage bias digolongkan pada beberapa sistem kegiatan seperti permukiman dan perdagangan dan jasa. \& penunjang. Pada kasus ini, kegiatan akan diuji keterkaitannya dengan adanya universitas, dimana adanya beberapa kegiatan mempunyai pengaruh dengan munculnya universitas.

Berubahnya pola guna lahan bisa berubah sesuai perkembangan kebutuhan dan pertambahan penduduk. Perubahan pola penggunaan lahan dapat menimbulkan fenomena penggunaan lahan dimanfaatkan untuk kegiatan lainnya. Seperti, penggunaan lahan yang semula sebagai tambak, menjadi lahan terbangun. Adanya universitas sangat membawa dampak besar pada perubahan guna lahan kawasan. Lahan yang awalnya adalah tambak dan tanah kosong dapat berubah menjadi lahan terbangun. Kepadatan bangunan kawasan kampus juga menyebabkan tidak teraturnya pola bangunan seperti bangunan perdagangan dan jasa terdapat pada kawasan kampus dan terlihat kurang tertata. Perubahan lahan akan terlihat oleh adanya toko/ruko pada jalan utama yaitu Jl. MT. Haryono, Jl. H.M.E Mokodompit dan Jl. A.H Nasution.

Tabel 2 Bentuk Perubahan Lahan

\begin{tabular}{|c|c|c|c|c|c|c|}
\hline \multirow[b]{2}{*}{ Perubahan } & \multicolumn{2}{|c|}{ Perubahan Lahan } & \multirow{2}{*}{$\begin{array}{c}\text { Bentuk } \\
\text { Perubahan }\end{array}$} & \multirow{2}{*}{$\begin{array}{c}\text { Besaran } \\
\text { Lahan } \\
\text { (Ha) }\end{array}$} & \multirow{2}{*}{$\begin{array}{c}\text { Sebaran } \\
\text { Aktivitas } \\
\text { (Kelurahan) }\end{array}$} & \multirow[b]{2}{*}{ Keterangan } \\
\hline & $\begin{array}{c}\text { Lahan } \\
\text { Sebelumnya }\end{array}$ & $\begin{array}{c}\text { Lahan } \\
\text { Sekarang }\end{array}$ & & & & \\
\hline Bermukim & $\begin{array}{l}\text { RTH, Tanah } \\
\text { Terbuka }\end{array}$ & Terbangun & $\begin{array}{l}\text { Perumahan, } \\
\text { Kos, } \\
\text { Kontrakan }\end{array}$ & 135,3 & $\begin{array}{l}\text { Keluahan } \\
\text { Kambu dan } \\
\text { Lalolara }\end{array}$ & Survey Sekunder \\
\hline $\begin{array}{l}\text { Perdaganga } \\
\mathrm{n} \text { dan Jasa }\end{array}$ & $\begin{array}{l}\text { RTH, } \\
\text { Tambak, } \\
\text { Tanah } \\
\text { Terbuka }\end{array}$ & Terbangun & $\begin{array}{l}\text { Rumah } \\
\text { makan, } \\
\text { Rental } \\
\text { Komputer, } \\
\text { Warnet, } \\
\text { Minimarket, } \\
\text { Warung, } \\
\text { Meubel, } \\
\text { Fotocopy } \\
\text { dan ATK }\end{array}$ & 9,7902 & $\begin{array}{l}\text { Keluahan } \\
\text { Kambu dan } \\
\text { Lalolara }\end{array}$ & Survey Primer \\
\hline
\end{tabular}




\begin{tabular}{|c|c|c|c|c|c|c|}
\hline \multirow[b]{2}{*}{ Perubahan } & \multicolumn{2}{|c|}{ Perubahan Lahan } & \multirow{2}{*}{$\begin{array}{c}\text { Bentuk } \\
\text { Perubahan }\end{array}$} & \multirow{2}{*}{$\begin{array}{c}\text { Besaran } \\
\text { Lahan } \\
\text { (Ha) }\end{array}$} & \multirow{2}{*}{$\begin{array}{c}\text { Sebaran } \\
\text { Aktivitas } \\
\text { (Kelurahan) }\end{array}$} & \multirow[b]{2}{*}{ Keterangan } \\
\hline & $\begin{array}{c}\text { Lahan } \\
\text { Sebelumnya }\end{array}$ & $\begin{array}{c}\text { Lahan } \\
\text { Sekarang }\end{array}$ & & & & \\
\hline Rekreasi & $\begin{array}{l}\text { RTH, } \\
\text { Tambak, } \\
\text { Tanah } \\
\text { Terbuka }\end{array}$ & Terbangun & $\begin{array}{l}\text { Game } \\
\text { Center, } \\
\text { Rental } \\
\text { VCD, } \\
\text { Persewaan } \\
\text { Komik dan } \\
\text { Lap. Futsal } \\
\text { indoor }\end{array}$ & 0,5225 & $\begin{array}{l}\text { Keluahan } \\
\text { Kambu dan } \\
\text { Lalolara }\end{array}$ & Survey Primer \\
\hline Penunjang & $\begin{array}{l}\text { RTH, } \\
\text { Tambak, } \\
\text { Tanah } \\
\text { Terbuka }\end{array}$ & Terbangun & $\begin{array}{l}\text { Butik, } \\
\text { Bengkel, } \\
\text { Salon, } \\
\text { Laundry }\end{array}$ & 3,4526 & $\begin{array}{l}\text { Keluahan } \\
\text { Kambu dan } \\
\text { Lalolara }\end{array}$ & Survey Primer \\
\hline
\end{tabular}

Sumber: Afriani, 2014

Perkembangan kawasan pada sekitar kampus sangat dipengaruhi oleh adanya perguruan tinggi dengan semua aktivitasnya. Perkembangan tersebut sangat signifikan seperti perkembangan aspek ekonomi yang dapat mempengaruhi lahan terbangun.

\section{B. Studi Kasus "Faktor-Faktor Yang Mempengaruhi Pola Penggunaan Lahan}

\section{Akibat Keberadaan Kawasan Pendidikan UNNES"}

Gunungpati adalah sebuah daerah pinggiran, sama halnya dengan Tembalang. Dua lokasi yang sama yang menjadi pilihan sebagai lokasi perguruan tinggi dengan skala tingkat nasional, dimana banyaknya mahasiswa sangat mempengaruhi perubahan fisik kawasan. Seperti perubahanlahan dan juga sistem aktivitas yang sangat terlihat jelas. Adanya perguruan tinggi mendapat banyak dampak positif tetapi banyak juga dampak negatif seperti berkurangnya ruang terbuka hijau karena adanya lahan terbangun yang membutuhkan banyak lahan kosong.

Masyarakat tetap yang telah menemptai kawasan gunungpati juga akan terkena imbas dari adanya perguruan tinggi tersebut. Basis penggunaan lahan yang awalnya adalah lahan pertnaian berubah menjadi pusat pendidikan, yang pasti akan mempengaruhi mata pencaharian masyarakat awal yang bekerja sebagai petani. Maka dari itu banyak alternatif muncul seperti mata pencaharian berubah menjadi pedagang atau membuat sebuah hunian untuk kebutuhan mahasiswa. Kawasan yang tumbuh dengan sangat pesat adalah kawasan sekarang, dimana pusat pendidikan berada pada kawasan tersebut. 
Tumbuhnya aspek ekonomi, sosial dan juga spasial tidak dapat dihindari. Daerah yang awal mula sepi menjadi ramai dengan adanya aktivitas baru. Kawasan sekaran sudah dapat disebut dengan pusat dari gunungpati itu sendiri. Berdasarkan hasil analisis, peta kawasan sekaran menunjukkan bahwa perkembangan pola ruang kawasan sekaran adalah memanjang mengikuti jalan. Hal tersebut disebabkan oleh berkembangnya pusta pendidikan di sepanjang jalan akan tumbuh aktivitas baru seperti adanya perdagangan dan jasa juga pusat pelayanan lainnya.

C. Studi Kasus "Pengaruh Keberadaan Perguruan Tinggi Terhadap Perubahan Morfologi Kawasan Sekitarnya (Universitas Jenderal Soedirman)"

Purwokerto adalah salah satu kecamatan yang berada pada Kabupaten Banyumas. Tetapi seolah-olah orang awam lebih mengetahui bahwa purwokerto adalah sebuah kabupaten sendiri dimana terdapat kampus berskala nasional yaitu Universitas Jenderal Soedirman. Sama halnya dengan kawasan atau wilayah lainnya, adanya perguruan tinggi snagat berpengaruh terutama pada perubahan penggunaan lahan dan juga fisik kawasan. Aktivitas yang terjadi membutuhkan sebuah fasilitasfasilitas penunjang untuk dapat memenuhi kebutuhan dari masyarakat awal yang menetap dan juga bagi kehidupan mahasiswa. Fasilitas penunjang yang dikaitkan adalah sebuah aspek dimana dapat menumbuhkan sebuah pusat kegiatan baru seperti aktivitas perdagangan dan jasa, aktivitas pertokoan, aksesibilitas yang juga sangat diperlukan dalam menjangkau kawasan yang cukup jauh. Dengan adanya perguruan tinggi juga menjadikan kawasan sekitar menjadi lebih padat. Berpengaruh terhadap beberapa lokasi, tidak hanya pada kawasan yang menjadi titik berdirinya perguruan tinggi, namun daerah lain di sekitar perguruan tinggi juga akan mendapatkan dampak, baik positif maupun negatif.

Perubahan penggunaan lahan jelas akan terjadi ketika sebuah aktivitas baru telah tumbuh pada suatu kawasan atau wilayah. Seperti akan terjadi perubahan penggunaan lahan dari basis awal sebuah lahan kosong akan menjadi lahan terbangun demi memenuhi sebuah kebutuhan baik bagi masyarakat maupun bagi mahasiswa itu sendiri. Banyaknya sebuah peluang menjadikan orang luar dari kawasan tersebut berbondong-bondong datang sehingga tidak hanya kebutuhan lahan yang semakin menipis tetapi ruang gerak didalam kawasan tersebut juga akan semakin habis. Lahan yang dulunya pertanian menjadi perdagangan dan jasa juga tempat hunian. Masyarakat yang dulunya bekerja sebagai petani berubah menjadi pedagang atau membuka tempat 
hunian sebagai kebutuhan mahasiswa. Dapat dilihat dengan jelas perbedaan pada tahun 2013 dimana titik sebuah kawasan yang menjadi pusat pendidikan dan juga kawasan sekitar menjadi snagat padat dan juga penuh.

Munculnya beberapa perumahan tidak dapat dihindari dari adanya aktivitas kampus. Banyak investor yang bahkan membeli sebuah lahan untuk didirikan perumahan ataupun pertokoan yang dapat menjadi salah satu fasilitas penunjang bagi masyarakat sekitar dan mahasiswa. Dampak negatif dari hal tersebut adalah kebutuhan lahan semakin meningkat dimana lahan kosong akan menjadi lahan terbangun dan menjadikan ruang terbuka hijau semakin berkurang. Peningkatan permintaan juga menjadikan kurangnya lahan kosong.

Beberapa lahan memang dimanfaatkan kembali menjadi sebuah ruang terbuka hijau ataupun di fungsikan kembali sebagai perkebunan dan juga persawahan. Tetapi tidak menutup kemungkinan lahan terbangun akan berkurang, justru lahan terbangun semakin bertambah dan juga padat. Bukan lagi berada pada kawasan berdirinya kampus tetapi sudah menyebar pada kawasan lain disekitar pusat pendidikan yang masih dapat dijangkau oleh mahasiswa dan juga developer maupun investor.

Pada kawasan pendidikan UNSOED pola atau tata ruang kawasan membentuk seperti gurita dan juga linear. Dimana aksesibilitas menuju pusat utama pendidikan. Hal tersebut menjadikan sistem transportasi menjadi penting pada kawasan pendidikan UNSOED. Bentuk linear juga menunjukkan bahwa pada koridor utama cenderung berfungsi sebagai kawasan pusat perdagangan dan jasa, sedangkan pada koridor lingkungan membentuk sebuah cluster tertentu.

Kesimpulan dari studi kasus yang telah dijabarkan diatas yaitu keberadaan perguruan tinggi universitas jenderal soedirman memang menjadi sebuah perubahan morfologi yang cukup signifikan terhadap kawasan pusat yang dijadikan sebagai lokasi pendidikan. Banyaknya tempat hunian dekat kampus memiliki sebuah alasan dimana aksesibilitas menjadi lebih mudah dan juga lebih dekat dalam mendekati kawasan pusat pendidikan. Untuk daerah sekitar yang telah terkena dampak dari adanya perguruan tinggi juga karena lahan yang ada pada kawasan utama tidak dapat menampung semua aktivitas yang akan terjadi seperti berkurangnya lahan sebagai tempat hunian sehingga memilih untuk menjauihi dari pusat pendidikan, dari sini dapat 
disimpulkan bahwa aksesibilitas sangat membantu dalam kebutuhan masyarakat dan juga mahasiswa itu sendiri.

\section{Studi Kasus "Dampak Spasial Kehadiran Kampus Universitas Diponegoro di} Kawasan Tembalang Semarang"

Universitas Diponegoro menjadi salah satu perguruan tinggi yang memiliki mahasiswa dari berbagai daerah, dan akan membutuhkan sebuah daya tampung baik secara spasial, sosial dan juga ekonomi. Hal tersebut akan mendorong sebuah pembangunan pada lokasi yang lebih layak untuk mengembangkan segi spasial, sosial dan juga ekonomi, sehingga lokasi awal yang berada di Pleburan secara bertahap dipindahkan lokasi menjadi di Tembalang.

Kondisi awal lokasi kampus UNDIP Tembalang yang masih sepi karena berada pada pinggiran kota, seiring berjalannya mengalami sebuah perubahan dimana segi spasial, sosial dan juga ekonomi menjadi sebuah poin utama dengan dijadikannya kawasan pendidikan tingi. Secara kawasan Tembalang dapat dibagi menjadi 2 zona yaitu

\section{Zona Pertama}

Zona ini dibatasi mulai dari jalan tol hingga kampus UNDIP. Pada zona ini penggunaan lahan yang mendominasi seperti permukiman, perdagangan dan jasa. Zona ini sangat berpengaruh dan juga dipengaruhi oleh adanya kampus UNDIP. Seperti permukiman masyarakat yang dapat dijadikan sebagai area kos untuk mahasiswa dan juga banyaknya perdagangan dan jasa pada masing-masing sisi koridor menjadikan lokasi sangat strategis untuk dapat pada aspek ekonomi dan spasial. Tetapi karena banyaknya mahasiswa berbanding terbalik dengan kondisi lahan yang ada sehingga semakin banyaknya lokasi lain yang dapat berubah sesuai kebutuhan. Aktivitas pada zona ini disebutkan sebagai pusat pendidikan dan wadah aktivitas mahasiswa.

\section{Zona Kedua}

Zona ini dimulai dari jalan tol menuju sumurboto stationery. Zona ini didominasi oleh pertokoan, perumahan dan perdagangan dan jasa. Dikatakan pada zona pertama dimana akan bertambahnya kebutuhan untuk mahasiswa, maka pada zona kedua ini sudah dirasakan akan kemacetan yang terjadi karena adanya kos-kosan 
mahasiswa, terdapat pula gedung arsip dan juga kantor Kecamatan Banyumanik dan Kelurahan Sumurboto dan juga menjadi jalan keluar masuk pintu tol menuju Semarang-Bawen. Dengan hadirnya kampus UNDIP menjadikan lokasi ini juga memadat seiring dengan pertumbuhan penduduk dan juga kebutuhan penduduk, pada koridor jalur zona kedua ini juga telah dipadati oleh perdagangan dan jasa dan juga toko. Pengembangan cluster dan perumahan juga cukup menarik perhatian developer dalam aspek ekonomi sehingga lahan semakin sedikit dan juga menjadi padat. Aktivitas pada zona ini disebut sebagai pusat pelayanan publik dan juga pusat pemerintahan dimana sektor informal juga ikut andil didalamnya. Disebut sebagai pusat pelayanan yaitu dengan adanya swalayan, SPBU, spa dan juga gedung olahraga.

Pada analisa karakteristik zona, dapat dilihat kembali pada zona 2 diketahui bahwa aktivitas seperti swalayan, bangunan pemerintahan dan juga perdagangan dan jasa ada karena adanya investor yang mampu mendirikan bangunan-bangunan tersebut. Sedangkan pada zona 1 di dominasi oleh bangunan kos-kosan dan juga kontrakan mahasiswa. Ada beberapa titik lagi yang dapat di kategorikan sebagai zona 3 yaitu pada kawasan ngesrep dimana di jumpai juga terdapat bangunan kos-kosan yang dibangun pada lahan luas dan terdapat beberapa kamar. Hal tersebut dikarenakan belum adanya lahan yang di wariskan oleh penduduk asli dan masih banyak investor yang ingin menggunakan lahan tersebut sebagai tempat kos. Sedangkan pada zona 1 dan zona 2 rumah dan tanah cukup sedikit dan juga ada yang sudah berbagi bersama penduduk asli atau orang luar yang membeli sebagai tempat kos. Pada zona 1 terdapat beberapa pertokoan dan swalayan, tidak terdapat bangunan pemerintah namun, keberadaan kampus UNDIP berada pada zona 1. Jumlah warung kecil lebih menjadi dominan daripada rumah penduduk asli, terdapat pula perdagangan dan jasa seperti tempat fotokopian, ruko, warung kecil dan juga tempat kos. Pada zona 2 aktivitas yang mendominasi lebih pada perdagangan dan jasa seperti ruko, swalayan dan juga bangunan pemerintahan. Sudah terdapat bangunan kos, tetapi masih relatif sedikit. Sedangkan pada zona 3 di dominasi oleh ruko yang cukup banyak karena lokasi berada pada jalan utama jalur besar.

Secara spasial terdapat perubahan yang cukup signifikan yang terjadi karena adanya kampus UNDIP. Seperti pada ruas jalan di mulai dari ngesrep hingga menuju UNDIP, lalu lintas yang tadinya sepi dan aktivitas yang kurang sudah mulai 
terdapat bangunan pertokoan, swalayan dan juga perdagangan dan jasa lainnya di sepanjang koridor sehingga adanya kemacetan juga tidak dapat di hindari lagi. Adanya berbagai investor yang cukup mengambil peluang dengan adanya kampus UNDIP ini, terdapat pula kecenderungan wajah baru dan juga penggunaan lahan yang semakin meningkat menunjukkan bahwa keberadaan kampus sangat berpengaruh. Selain memberikan dampak positif, adanya kampus juga memberikan beberapa dampak negatif seperti terjadinya kemacetan, kebutuhan lahan yang semakin meningkat dan juga memberikan kurang nyamannya aktivitas di sekitarnya.

\section{E. Studi Kasus "Identifikasi Perubahan Penggunaan Lahan di Kawasan Pendidikan Tinggi Bogor"}

Perguruan tinggi menjadi salah satu aspek yang dapat memberikan sebuah perubahan pada suatu kawasan atau wilayah, seperti pada beberapa lokasi yaitu Kecamatan Dramaga, Bogor dan Kecamatan Jatinagor, Sumedang. Dua kecamatan yang memiliki sebuah perubahan karena adanya aktivitas pendidikan perguruan tinggi. Pada awalnya penggunaan lahan pada dua kecamatan tersebut adalah perkebunan dan juga persawahan penduduk atau yang tergolong sebagai penggunaan lahan pertanian dengan masyarakat sebagai pekerjanya. Setelah adanya pemindahan aktivitas perguruan tinggi, dua kecamatan tersebut mengalami perubahan yaitu menjadi penggunaan lahan permukiman padat penduduk dan juga pekerjaan masyarakat yaitu perdagangan dan jasa.

Keberadaan perguruan tinggi sangat besar, terutama terhadap kawasan atau wilayah yang ditetapkan sebagai lokasi perguruan tinggi. Dilihat dari analisis yang telah dilakukan dapat dilihat beberapa perubahan yang sangat signifikan terjadi pada dua kecamatan dimana sebagai aktivitas perguruan tinggi. Pada kesimpulan ini dapat di sarankan, dalam pemilihan lokasi perguruan tinggi hendaknya benar-benar dilakukan dan diteliti lebih lanjut, agar perubahan fungsi lahan terlalu besar tidak terjadi dan juga tidak merugikan masyarakat asli kawasan atau wilayah tersebut.

\section{F. Studi Kasus "Pengaruh Keberadaan kampus Terhadap Perubahan Fisik Kawasan Disekitarnya (Studi Kasus Yogyakarta)"}

Yogyakarta disebut juga sebagai kota pendidikan, dimana banyaknya perguruan tinggi yang terdapat hampir di seluruh penjuru kota tersebut. Pada studi kasus saat ini lokasi yang akan di ambil yaitu kawasan babarsari, Kecamatan Depok, Yogyakarta. 
Analisis ini digunakan untuk melihat fisik kawasan dari suatu perubahan pola ataupun tata ruang kawasannya. Dalam analisis figure ground ini kawasan babarsari dinilai sebagai kawasan heterogen berdasarkan hasil analisis. Yaitu massa bangunan dengan macam bentuk dan jarak. Blok sebagai definisi sisi sebab massa bangunan pada kanan dan kiri yang menumpuk dan mengerumpun.

Penggunaan lahan dikelompokkan menjadi 3 yaitu pertanian, lahan terbangun dan lahan tidak terbangun. Pada setiap tahun dalam time series, lahan pertanian selalu berkurang pada tahun

2017 menjadi 23,68\%. Jika kurang dikendalikan maka ruang terbuka hijau pada kawasan babarsari juga akan mengalami penurunan. Perubahan dari penggunaan lahan tidak lain juga mendapat pengaruh dari adanya pola aktivitas kawasan yang berubah, seperti

1. Perubahan fisik jalur jalan karena aktivitas sosial;

2. Lahan pertanian menjadi terbangun;

3. Menjadikan fungsi komersial sebagai poin kebutuhan.

Fasilitas sekitar perguruan tinggi juga memerlukan fasilitas penunjang lain seperti aksesibilitas dengan adanya jalur jalan yang memang akan merubah sebuah aktivitas dari hampir keseluruhan aktivitas asli. Aktivitas lain adalah kebutuhan lahan kosong untuk memenuhi hunian terhadap permintaan yang tinggi. Jika tidak dilakukan penataan khusus maka tidak menutup kemungkinan lahan kosong dan juga pertanian semakin lama akan beralih fungsi sebagai lahan terbangun karena sebuah kebutuhan. 
Tabel 6 Perbandingan Studi Kasus Pengaruh Kawasan Pendidikan Perguruan Tinggi Terhadap Perubahan Guna Lahan

\begin{tabular}{|c|c|c|c|c|c|c|c|}
\hline \multirow[b]{2}{*}{ No } & \multirow[b]{2}{*}{ Sasaran } & \multicolumn{6}{|c|}{ Pengaruh Kawasan Pendidikan Perguruan Tinggi Terhadap Perubahan Guna Lahan } \\
\hline & & $\begin{array}{c}\text { Pengaruh } \\
\text { Keberadaan } \\
\text { Universitas } \\
\text { Haluoleo } \\
\text { Terhadap } \\
\text { Perubahan Tata } \\
\text { Guna Lahan di } \\
\text { Kawasan } \\
\text { Andonuohu Kota } \\
\text { Kendari }\end{array}$ & $\begin{array}{c}\text { Faktor-Faktor yang } \\
\text { Mempengaruhi } \\
\text { Pola Penggunaan } \\
\text { Lahan Akibat } \\
\text { Keberadaan } \\
\text { Kawasan } \\
\text { Pendidikan } \\
\text { UNNES } \\
\text { Kecamatan } \\
\text { Sekaran }\end{array}$ & $\begin{array}{c}\text { Pengaruh } \\
\text { Keberadaan } \\
\text { Perguruan Tinggi } \\
\text { Terhadap Perubahan } \\
\text { Morfologi Kawasan } \\
\text { Sekitarnya (Kawasan } \\
\text { Pendidikan } \\
\text { UNSOED) }\end{array}$ & $\begin{array}{c}\text { Dampak Spasial } \\
\text { Kehadiran Kampus } \\
\text { Universitas } \\
\text { Diponegoro Di } \\
\text { Kawasan Tembalang } \\
\text { Semarang }\end{array}$ & $\begin{array}{c}\text { Identifikasi } \\
\text { Perubahan } \\
\text { Penggunaan Lahan di } \\
\text { Kawasan Pendidikan } \\
\text { Tinggi Bogor }\end{array}$ & $\begin{array}{c}\text { Pengaruh } \\
\text { Keberadaan kampus } \\
\text { Terhadap Perubahan } \\
\text { Fisik Kawasan } \\
\text { Disekitarnya (Studi } \\
\text { Kasus Yogyakarta) }\end{array}$ \\
\hline 1. & $\begin{array}{l}\text { Perkembangan } \\
\text { Penggunaan } \\
\text { Lahan Di } \\
\text { Kawasan } \\
\text { Pendidikan } \\
\text { Perguruan Tinggi }\end{array}$ & $\begin{array}{l}\text { Perkembangan } \\
\text { penggunaan lahan } \\
\text { pada kawasan } \\
\text { Pendidikan } \\
\text { Perguruan Tinggi di } \\
\text { Kota Kendari terus } \\
\text { meningkat dari tahun } \\
2006 \text { hingga tahun } \\
2010 \text { Terjadi } \\
\text { perubahan mulai dari } \\
\text { lahan terbangun } \\
\text { menjadi lahan tidak } \\
\text { terbangun. } \\
\text { Sedangkan untuk } \\
\text { lahan non terbangun } \\
\text { semakin berkurang } \\
\text { dan sedikit. Lahan } \\
\text { tidak terbangun } \\
\text { menjadi lahan } \\
\text { terbangun seiring } \\
\text { adanya Universitas } \\
\text { Haluoleo yang } \\
\text { menyebabkan } \\
\text { perkembangan } \\
\text { kawasan sekitar. }\end{array}$ & 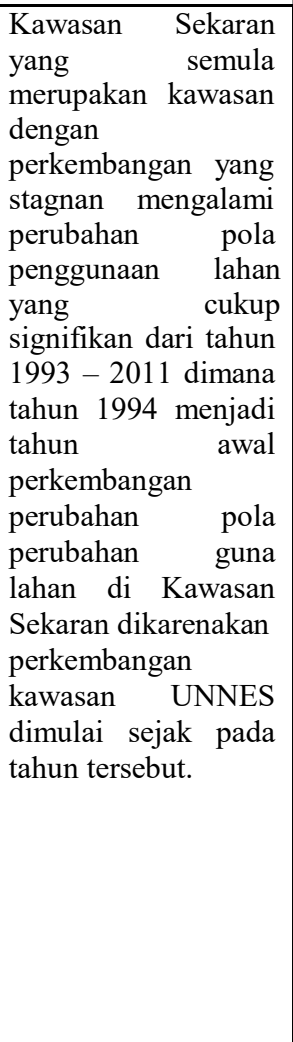 & 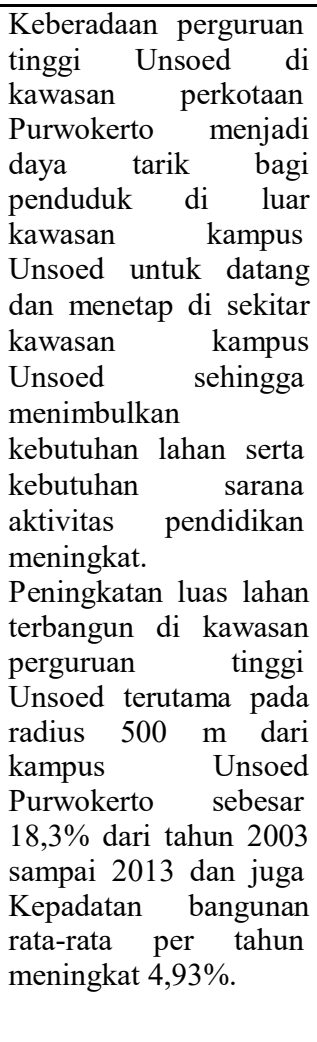 & $\begin{array}{l}\text { Secara spasial terdapat } \\
\text { perubahan yang cukup } \\
\text { signifikan yang terjadi } \\
\text { karena adanya kampus } \\
\text { UNDIP. Seperti pada } \\
\text { ruas jalan di mulai dari } \\
\text { ngesrep hingga menuju } \\
\text { UNDIP, lalu lintas } \\
\text { yang tadinya sepi dan } \\
\text { aktivitas yang kurang } \\
\text { sudah mulai terdapat } \\
\text { bangunan pertokoan, } \\
\text { swalayan dan juga } \\
\text { perdagangan dan jasa } \\
\text { lainnya di sepanjang } \\
\text { koridor sehingga } \\
\text { adanya kemacetan juga } \\
\text { tidak dapat di hindari } \\
\text { lagi. Adanya berbagai } \\
\text { investor yang cukup } \\
\text { mengambil peluang } \\
\text { dengan adanya kampus } \\
\text { UNDIP ini, terdapat } \\
\text { pula kecenderungan } \\
\text { wajah baru dan juga } \\
\text { penggunaan lahan yang } \\
\text { semakin meningkat } \\
\text { menunjukkan bahwa } \\
\text { keberadaan kampus }\end{array}$ & 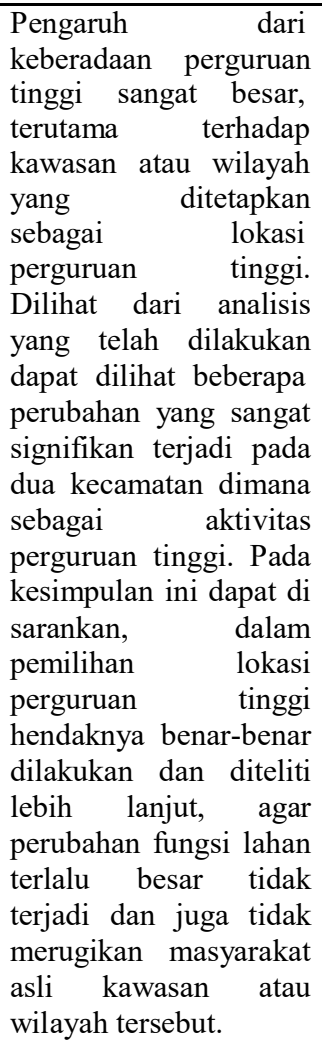 & 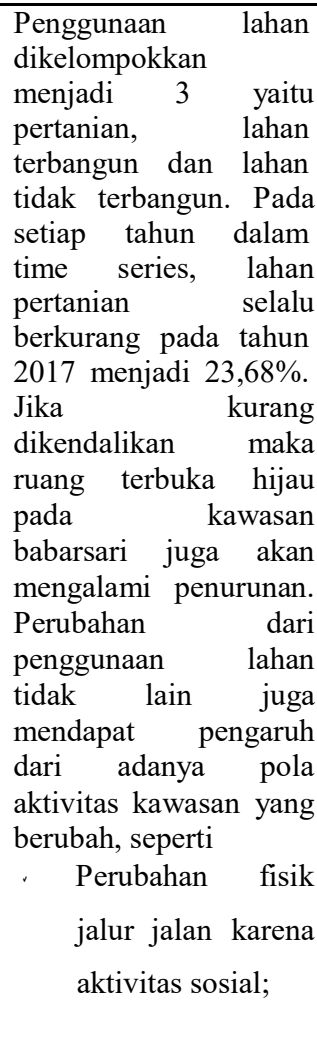 \\
\hline
\end{tabular}




\begin{tabular}{|c|c|c|c|c|c|c|c|}
\hline \multirow[b]{2}{*}{ No } & \multirow[b]{2}{*}{ Sasaran } & \multicolumn{6}{|c|}{$\begin{array}{l}\text { Pengaruh Kawasan Pendidikan Perguruan Tinggi Terhadap Perubahan Guna Lahan } \\
\end{array}$} \\
\hline & & $\begin{array}{c}\text { Pengaruh } \\
\text { Keberadaan } \\
\text { Universitas } \\
\text { Haluoleo } \\
\text { Terhadap } \\
\text { Perubahan Tata } \\
\text { Guna Lahan di } \\
\text { Kawasan } \\
\text { Andonuohu Kota } \\
\text { Kendari } \\
\end{array}$ & $\begin{array}{c}\text { Faktor-Faktor yang } \\
\text { Mempengaruhi } \\
\text { Pola Penggunaan } \\
\text { Lahan Akibat } \\
\text { Keberadaan } \\
\text { Kawasan } \\
\text { Pendidikan } \\
\text { UNNES } \\
\text { Kecamatan } \\
\text { Sekaran } \\
\end{array}$ & $\begin{array}{c}\text { Pengaruh } \\
\text { Keberadaan } \\
\text { Perguruan Tinggi } \\
\text { Terhadap Perubahan } \\
\text { Morfologi Kawasan } \\
\text { Sekitarnya (Kawasan } \\
\text { Pendidikan } \\
\text { UNSOED) }\end{array}$ & $\begin{array}{c}\text { Dampak Spasial } \\
\text { Kehadiran Kampus } \\
\text { Universitas } \\
\text { Diponegoro Di } \\
\text { Kawasan Tembalang } \\
\text { Semarang }\end{array}$ & $\begin{array}{c}\text { Identifikasi } \\
\text { Perubahan } \\
\text { Penggunaan Lahan di } \\
\text { Kawasan Pendidikan } \\
\text { Tinggi Bogor }\end{array}$ & $\begin{array}{c}\text { Pengaruh } \\
\text { Keberadaan kampus } \\
\text { Terhadap Perubahan } \\
\text { Fisik Kawasan } \\
\text { Disekitarnya (Studi } \\
\text { Kasus Yogyakarta) }\end{array}$ \\
\hline & & & & & $\begin{array}{lr}\text { sangat } & \text { berpengaruh. } \\
\text { Selain } & \text { memberikan } \\
\text { dampak positif, adanya } \\
\text { kampus } & \text { juga } \\
\text { memberikan } & \text { beberapa } \\
\text { dampak negatif seperti } \\
\text { terjadinya } & \text { kemacetan, } \\
\text { kebutuhan } & \text { lahan yang } \\
\text { semakin } & \text { meningkat } \\
\text { dan juga } & \text { memberikan } \\
\text { kurang } & \text { nyamannya } \\
\text { aktivitas di sekitarnya }\end{array}$ & & $\begin{array}{l}\text { Lahan pertanian } \\
\text { menjadi } \\
\text { terbangun; } \\
\text { Menjadikan } \\
\text { fungsi komersial } \\
\text { sebagai poin } \\
\text { kebutuhan. } \\
\text { Fasilitas sekitar } \\
\text { perguruan tinggi juga } \\
\text { memerlukan fasilitas } \\
\text { penunjang lain seperti } \\
\text { aksesibilitas dengan } \\
\text { adanya jalur jalan yang } \\
\text { memang akan merubah } \\
\text { sebuah aktivitas dari } \\
\text { hampir keseluruhan } \\
\text { aktivitas asli. Aktivitas } \\
\text { lain adalah kebutuhan } \\
\text { lahan kosong untuk } \\
\text { memenuhi hunian } \\
\text { terhadap permintaan } \\
\text { yang tinggi. Jika tidak } \\
\text { dilakukan penataan } \\
\text { khusus maka tidak } \\
\text { menutup kemungkinan } \\
\text { lahan kosong dan juga } \\
\text { pertanian semakin } \\
\text { lama akan beralih } \\
\text { fungsi sebagai lahan } \\
\text { terbangun karena } \\
\end{array}$ \\
\hline
\end{tabular}




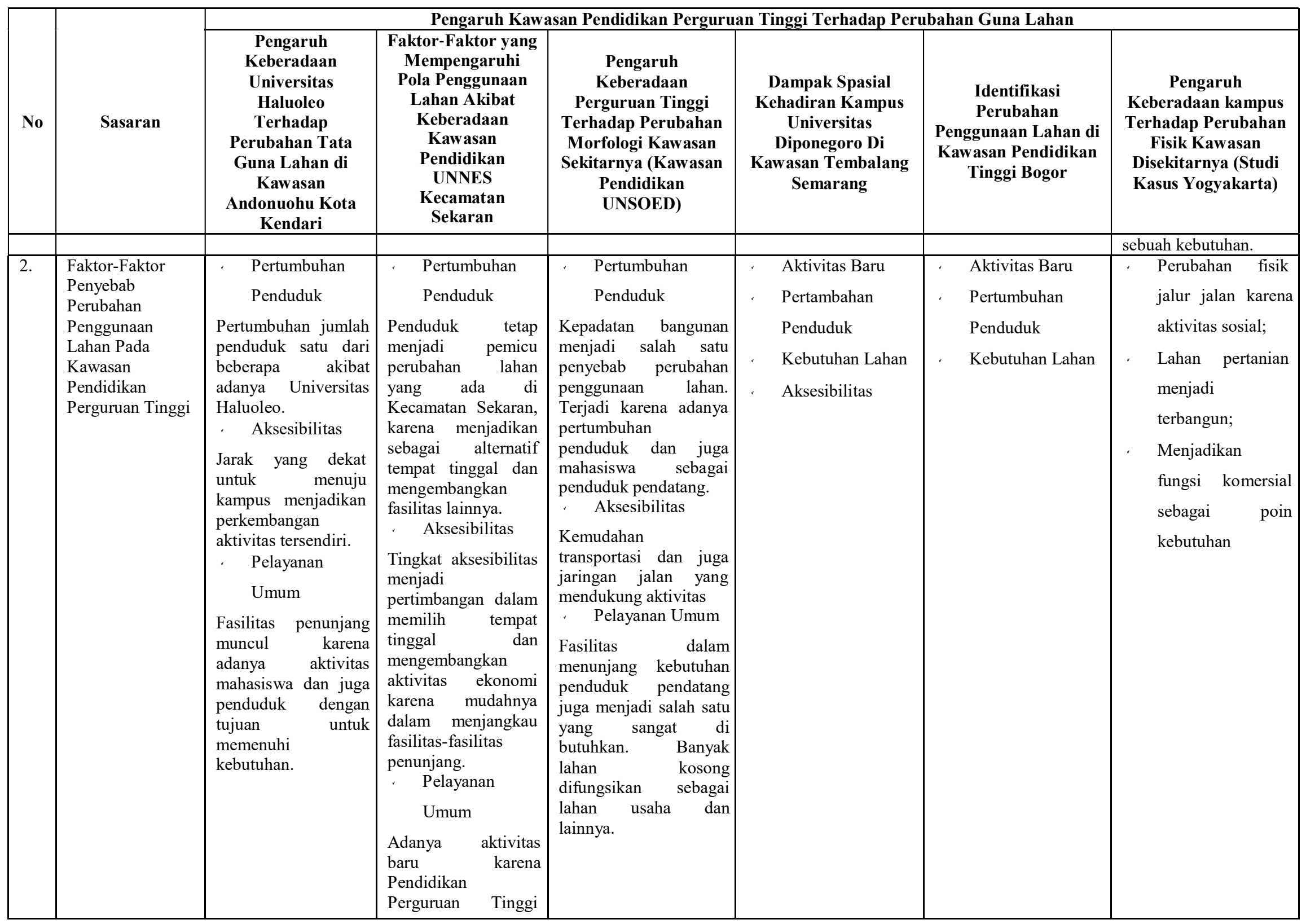




\begin{tabular}{|c|c|c|c|c|c|c|c|}
\hline \multirow[b]{2}{*}{ No } & \multirow[b]{2}{*}{ Sasaran } & \multicolumn{6}{|c|}{ Pengaruh Kawasan Pendidikan Perguruan Tinggi Terhadap Perubahan Guna Lahan } \\
\hline & & $\begin{array}{c}\text { Pengaruh } \\
\text { Keberadaan } \\
\text { Universitas } \\
\text { Haluoleo } \\
\text { Terhadap } \\
\text { Perubahan Tata } \\
\text { Guna Lahan di } \\
\text { Kawasan } \\
\text { Andonuohu Kota } \\
\text { Kendari }\end{array}$ & $\begin{array}{c}\text { Faktor-Faktor yang } \\
\text { Mempengaruhi } \\
\text { Pola Penggunaan } \\
\text { Lahan Akibat } \\
\text { Keberadaan } \\
\text { Kawasan } \\
\text { Pendidikan } \\
\text { UNNES } \\
\text { Kecamatan } \\
\text { Sekaran }\end{array}$ & $\begin{array}{c}\text { Pengaruh } \\
\text { Keberadaan } \\
\text { Perguruan Tinggi } \\
\text { Terhadap Perubahan } \\
\text { Morfologi Kawasan } \\
\text { Sekitarnya (Kawasan } \\
\text { Pendidikan } \\
\text { UNSOED) }\end{array}$ & $\begin{array}{c}\text { Dampak Spasial } \\
\text { Kehadiran Kampus } \\
\text { Universitas } \\
\text { Diponegoro Di } \\
\text { Kawasan Tembalang } \\
\text { Semarang }\end{array}$ & $\begin{array}{c}\text { Identifikasi } \\
\text { Perubahan } \\
\text { Penggunaan Lahan di } \\
\text { Kawasan Pendidikan } \\
\text { Tinggi Bogor }\end{array}$ & $\begin{array}{c}\text { Pengaruh } \\
\text { Keberadaan kampus } \\
\text { Terhadap Perubahan } \\
\text { Fisik Kawasan } \\
\text { Disekitarnya (Studi } \\
\text { Kasus Yogyakarta) }\end{array}$ \\
\hline & & & $\begin{array}{l}\text { menjadikan fasilitas- } \\
\text { fasilitas yang ada } \\
\text { semakin bertambah. }\end{array}$ & & & & \\
\hline
\end{tabular}




\section{KESIMPULAN DAN SARAN \\ Kesimpulan}

Berdasarkan penjabaran dari beberapa studi kasus yang telah dikaji lebih lanjut, kesimpulan yang dapat diambil yaitu sebuah aktivitas baru, seperti adanya perguruan tinggi pada suatu kawasa atau wilayah sangat berdampak pada wilayah dan juga masyarakat sekitar. Dilihat dari analisis yang telah dilakukan dapat dilihat beberapa perubahan yang sangat signifikan terjadi pada lokasi-lokasi dimana sebagai aktivitas perguruan tinggi. Pada kesimpulan ini dapat di sarankan, dalam pemilihan lokasi perguruan tinggi hendaknya benar-benar dilakukan dan diteliti lebih lanjut, agar perubahan fungsi lahan terlalu besar tidak terjadi dan juga tidak merugikan masyarakat asli kawasan atau wilayah tersebut. Dampak lainnya seperti lalu lintas yang tadinya sepi dan aktivitas yang kurang sudah mulai terdapat lahan terbangun sebagai perdagangan dan jasa juga sebagai hunian sehingga adanya kemacetan juga tidak dapat di hindari lagi. Adanya berbagai investor yang cukup mengambil peluang dengan adanya perguruan tinggi ini, terdapat pula kecenderungan wajah baru dan juga penggunaan lahan yang semakin meningkat menunjukkan bahwa keberadaan perguruan tinggi sangat berpengaruh. Selain memberikan dampak positif, adanya perguruan tinggi juga memberikan beberapa dampak negatif seperti terjadinya kemacetan, kebutuhan lahan yang semakin meningkat dan juga memberikan kurang nyamannya aktivitas di sekitarnya.

\section{Saran}

Dalam pemilihan lokasi perguruan tinggi hendaknya benar-benar dilakukan dan diteliti lebih lanjut, agar perubahan fungsi lahan terlalu besar tidak terjadi dan juga tidak merugikan masyarakat asli kawasan atau wilayah tersebut. Hal ini dinilai sangat penting untuk tetap diperhatikan karena dampak yang didapatkan bukan hanya masyarakat awal yang menetap tetapi juga akan berdampak pada mahasiswa yang menjadi kurang nyaman dengan adanya aktivitas-aktivitas tersebut.

\section{DAFTAR PUSTAKA}

Bintarto, R. (1989). Interaksi Kota Desa dan Permasalahannya. Jakarta: Ghalia Indonesia. Jayadinata, Johara T. (1986). Tata Guna Tanah dalam Perencanaan Pedesaan, dan Wilayah. Bandung: Penerbit Institut Teknologi Bandung (ITB)

Jayadinata, Johara T. (1999). Tata Guna Tanah Dalam Perencanaan Pedesaan Perkotaan \& Wilayah, Cetakan ketiga, Penerbit ITB Bandung, Bandung

Sujarto. Djoko. (1989). Faktor Sejarah Perkembangan Kota Dalam Perencanaan Perkembangan Kota. Bandung. Fakultas Teknik Sipil Dan Perencanaan Bandung.

Yunus, Sabari. (2005). Struktur Tata Ruang Kota. Yogyakarta: Pustaka Pelajar 
Munggiarti, A., \& Buchori, I. (2015). Pengaruh keberadaan perguruan tinggi terhadap perubahan morfologi kawasan sekitarnya. Geoplanning: Journal of Geomatics and Planning, 2(1), 51-68.

Prasetyo, Y., \& Hariyono, P. (2014). Dampak Spasial Kehadiran Kampus Universitas Diponegoro 01 Kawasan Tembalang Semarang (The Spatial Impact of the College Attendance at Diponegoro University Area of Tembalang Semarang). Tesa Arsitektur, Journal of Architectural Discourses, 12(1), 58.

Pratiwi, R. I., \& Agustina, I. H. (2019). Identifikasi Perubahan Penggunaan Lahan di Kawasan Pendidikan Tinggi (Studi Kasus di Kecamatan Dramaga Kabupaten Bogor dan Kecamatan Jatinangor Kabupaten Sumedang).

Wulangsari, A., \& Pradoto, W. (2013). Faktor-Faktor yang Mempengaruhi Pola Penggunaan Lahan Akibat Keberadaan Kawasan Pendidikan Unnes (Studi Kasus: Kawasan Sekaran, Kecamatan Gunungpati). Teknik PWK (Perencanaan Wilayah Kota), 2(3), 468-480.

Ningsih, T. R. (2017). Pengaruh Keberadaan Kampus Terhadap Perubahan Fisik Kawasan Di Sekitarnya (Studi Kasus: Kawasan Babarsari, Kecamatan Depok, Yogyakarta). Jurnal Pengembangan Kota, 5(2), 159-165.

Abdul, Muiz. (2009). Analisis Perubahan Penggunaan Lahan di Kabupaten Sukabumi [Tesis], Sekolah Pascasarjana, Institut Pertanian Bogor, Bogor.

Amiruddin, Afriani. (2012). Pengaruh Keberadaan Universitas Haluoleo Terhadap Perubahan Tata Guna Lahan Di Kawasan Andonuohu Kota Kendari, Program Studi S1 Perencanaan Wilayah dan Kota, Fakultas Teknik Universitas Diponegoro, Semarang.

Hamzah, F. Rachman. (2010). Kajian Pola Spasial Pertumbuhan Kawasan Perumahan Dan Permukiman Di Kecamatan Limboto Kabupaten Gorontalo”, Program Pascasarjana Magister Teknik Pembangunan Wilayah dan Kota, Fakultas Teknik Universitas Diponegoro, Semarang.

Undang-Undang Republik Indonesia Nomor 12 Tahun 2012 Tentang Pendidikan Perguruan Tinggi 